\section{Controlling Red Threeawn on Abandoned Cropland with Ammonium Nitrate ${ }^{1}$}

\section{N. HYDER AND R. E. BEMENT}

Range Scientists, Plant Science Research Division, Agricultural Research Service, U.S. Department of Agriculture, Fort Collins, Colorado.

\section{Highlight}

In our experience, red threeawn is more sensitive to $\mathbf{N}$ fertilizer than any other species. This sensitivity is fortunate because a low rate $(20 \mathrm{lb} . / \mathrm{acre})$ of $\mathbf{N}$ fertilization controlled red threeawn, improved botanical composition, and increased herbage yield on an abandoned plowed field on the Central Great Plains. This work suggests the need for additional research to determine whether $20 \mathrm{lb}$. N/acre may cause succession to bypass the static Aristida stage and change botanical composition more quickly to desirable forage species.

This paper presents a case of nitrogen-induced plant mortality and secondary succession on an abandoned cropland on shortgrass plains in Colorado. The subject is primarily a technical matter at the present time. Nevertheless, sensitivity of red threeawn (Aristida longiseta Steud.) to ammonium nitrate suggests practical value. We have about 5 million acres of

${ }^{1}$ Cooperative investigations of the Plant Science Research Division, Agricultural Research Service, U.S. Department of Agriculture, and the Colorado Agricultural Experiment Station, Fort Collins. Scientific Series Paper No. 1691, Colorado Agricultural Experiment Station. Received October 14, 1971. abandoned cropland in the Central Great Plains. Many of the plowed fields were abandoned 40 years ago, but remain in the Aristida stage (Costello, 1944) of secondary succession because blue grama (Bouteloua gracilis (H.B.K.) Lag.) has little capacity to reestablish by seed on shortgrass plains (Hyder et al., 1971). A simple treatment that would reduce red threeawn and increase forage production on the abandoncd croplands could be valuable.

The objective was to study degrees of tolerance among species to nitrogen fertilizer. If some species have low requirements and tolerances for nitrogen while others have high requirements, we can manipulate botanical composition and redirect secondary succession by applying nitrogen fertilizer.

\section{Methods}

This experiment included an untreated check, 5 rates of nitrogen $(\mathrm{N})$ and 1 rate of phosphorus (P) in 4 randomized blocks; but the treatments were combined in a $6 \mathrm{~N}$ by $2 \mathrm{P}$ factorial experiment. The $\mathrm{N}$ rates were $20,40,60,100$, and $200 \mathrm{lb}$./acre, and the $\mathrm{P}$ rate was 20 lb./acre. Treble super-phosphate and ammonium nitrate were applied surface broadcast annually in the fall of 1963, 1964, and 1965. Herbage yields and botanical composition by weight were sampled in August each year following fertilization $(1964,1965,1966)$ and in 3 additional years (1967, 1968, 1969). Oven dry weights and composition percentages are reported. The plots were established on McGrew sandy loam at the Central Plains Experimental Range near Nunn, Colorado.

\section{Results}

Control of Red Threeawn

Within 2 years, fertilization at all rates of $\mathrm{N}$ reduced the yield of red threeawn below that on unfertilized plots (Table 1). Red 
Table 1. Percentage change (relative to unfertilized plots) in the yield of red threeawn due to fall fertilization at 5 rates of $N$ (lb./acre) in 1963, 1964, and 1965 .

\begin{tabular}{|c|c|c|c|c|c|}
\hline \multirow[b]{2}{*}{ Year } & \multicolumn{5}{|c|}{ Rate of $\mathrm{N}$ applied } \\
\hline & 20 & 40 & 60 & 100 & 200 \\
\hline 1964 & +6 & -1 & & -30 & -20 \\
\hline 1965 & -26 & -30 & -9 & -35 & -8 \\
\hline 1966 & -52 & -82 & -88 & -100 & -100 \\
\hline 19671 & -69 & -90 & -100 & -100 & -100 \\
\hline $1968^{1}$ & -35 & -41 & -66 & -80 & -100 \\
\hline 19691 & -9 & -24 & -66 & -83 & -100 \\
\hline
\end{tabular}

${ }^{1}$ Residual effects of $\mathrm{N}$ were obtained in the last 3 years.

threeawn continued to decrease in the third year of fertilization and in the first year of residual effects (1967), when fertilization rates of 20 and $40 \mathrm{lb}$. N/acre had reduced red threeawn 69 and $90 \%$, respectively. Reductions of $100 \%$ resulted from 60 or more $\mathrm{lb}$. N/acre applied in 3 consecutive years. Red threeawn recovered rapidly in the second and third years (1968 and 1969) of residual effects where the rate of fertilization had been

Table 2. Mean annual herbage yield (lb./acre) and annual precipitation (inches).

\begin{tabular}{lcc}
\hline \hline & $\begin{array}{c}\text { Mean } \\
\text { herbage } \\
\text { yield }^{1}\end{array}$ & Precipitation $^{2}$ \\
Year & $473 \mathrm{a}$ & 4.3 \\
1964 & $2052 \mathrm{~d}$ & 14.8 \\
1965 & $1545 \mathrm{c}$ & 11.0 \\
1966 & $2730 \mathrm{e}$ & 22.9 \\
19673 & $911 \mathrm{~b}$ & 13.1 \\
$1968^{3}$ & $622 \mathrm{a}$ & 16.4 \\
19693 & 1889 & 13.8 \\
Mean & 189
\end{tabular}

${ }_{1}$ Amounts followed by the same letter are not different at $95 \%$ probability. Yields by individual rates of $\mathrm{N}$ fertilizer are shown in Fig. 2. These mean yields are averaged over all rates of $N$, which were applied in the fall preceding each of the first 3 years.

2 The mean annual precipitation over the past 30 years was 12.2 inches. The lowest amount on record was 4.3 inches in 1964 and the highest amount was 22.9 inches in 1967.

${ }^{3}$ Residual effects of $\mathrm{N}$ were measured in the last 3 years.
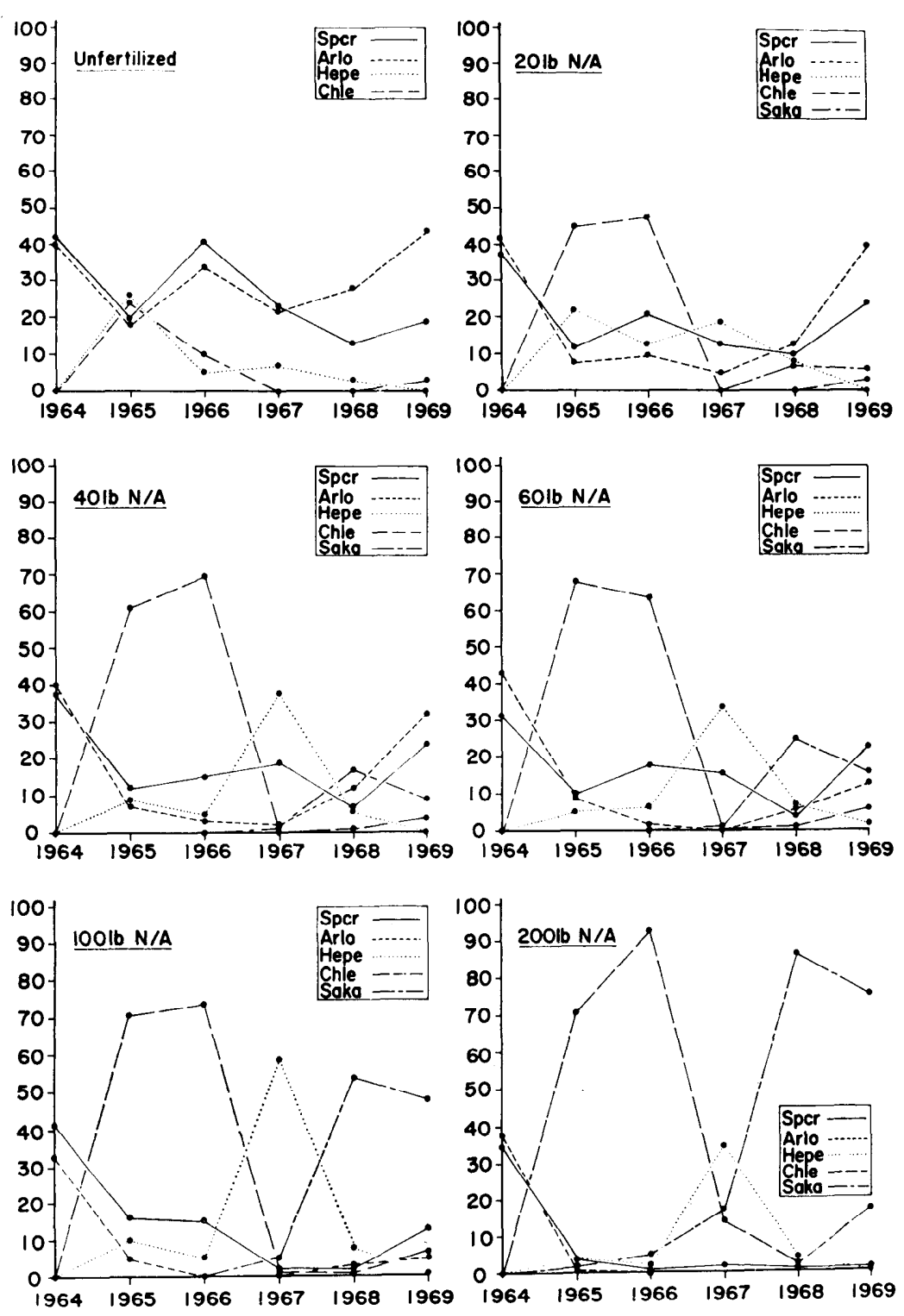

FIg. 1. Botanical composition (\% by oven dry weight) of 5 species (Spcr $=$ sand dropseed, Arlo $=$ red threeawn, Hepe $=$ prairie sunflower, Chle $=$ slimleaf goosefoot, and Saka $=$ Russianthistle) on abandoned cropland fertilized with ammonium nitrate in the fall 1963, 1964, and 1965.

20 and $40 \mathrm{lb}$. N/acre. Thus, continuous fertilization at a low rate of $\mathrm{N}$ would be needed to maintain control.

\section{Botanical Composition}

Five species accounted for $60 \%$ or more of herbage dry matter yields. Two were perennial pioneer grasses [red threeawn and sand dropseed (Sporobolus cryptandrus (Torr.) A. Gray)] and three were annual forbs [slimleaf goosefoot (Chenopodium leptophyllum Nutt.), prairie sunflower (Helianthus petiolaris Nutt.), and Russianthistle (Salsola kali tenuifolia Tausch.)]. Of these 5 species, red threeawn and slimleaf goosefoot are least desirable as forage for cattle.

Percentage contributions of these 5 species to total herbage yields are shown in Figure 1 by years and $\mathrm{N}$ rates. Severe drouth in 1964 (the first year after fall fertilization) prevented growth of annual species and killed some perennial pioneer grasses. Thus, in 1965, the 


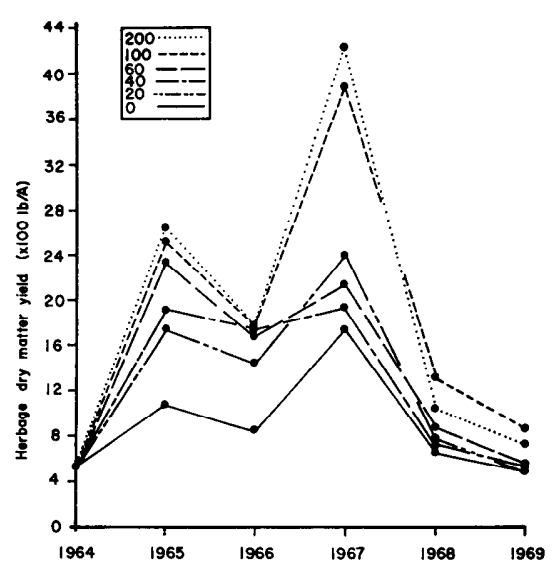

Fig. 2. Herbage yields on abandoned cropland fertilized with ammonium nitrate at the rates shown in the legend, in the fall 1963, 1964, and 1965. Residual responses were obtained in the last three years.

herbage contained a large proportion of annual species, even on unfertilized plots. Perennial pioneer grasses recovered from drouth in subsequent years, but their contribution to composition varied with precipitation and the amount of $\mathrm{N}$ applied in 3 consecutive years.

Nitrogen fertilization reduced perennial pioneer grasses and increased annual forbs. Red threeawn was more susceptible to $\mathrm{N}$ than sand dropseed, but both species were nearly eliminated by 60 lb. or more of N per acre. By 1969 , the third year of residual effects, these grasses were coming back on all plots except those fertilized at $200 \mathrm{lb}$. of $\mathrm{N} / \mathrm{acre}$.

Secondary succession after fertilization was stopped proceeded from slimleaf goosefoot to prairie sunflower, to Russianthistle, to pioneer perennial grasses. At all rates of $\mathbf{N}$, slimleaf goosefoot became dominant by replacing perennial pioneer grasses in the second and third years (1965 and 1966). Prairie sunflower replaced slimleaf goosefoot as dominant species in 1967. The degree of dominance attained by prairie sunflower increased with increase in rate of $\mathrm{N}$ up to 100 lb./acre. Perennial pioneer grasses regained dominance in 1968 and 1969 where the rate of $\mathrm{N}$ had been 20 or $10 \mathrm{lb}$./acre. However, at 60 lb. N/acre, Russianthistle followed prairie sunflower as dominant in 1968 and remained as codominant with perennial pioneer grasses in 1969. At 100 and $200 \mathrm{lb}$. N/acre, Russianthistle attained dominance in both 1968 and 1969, but its stands were so thick in 1969 that plant height seldom exceeded 5 inches.

\section{Herbage Dry Matter Yields}

Nitrogen rates, years of harvest, and $\mathrm{N}$ by year interaction were sources of highly significant $(99 \%)$ variation in herbage dry matter yields. Phosphorus failed to change the overall yield or botanical composition.

Herbage yields were low in the "dry" season of 1964 (Table 2). In subsequent years, including the last 3 years of residual responses, $\mathrm{N}$ increased herbage yields (Fig 2). The largest increase due to $\mathrm{N}$ occurred in 1967, which was the first year of residual responses and also was the wettest year on record at that station. Over all years and treatments, the yields varied about 10 fold-from about 400 to 4000 lb./acre on an oven dry basis. These yields from abandoned cropland were greater, even without fertilization, than those on adjacent unplowed blue grama range.

Over all 6 years, the mean annual increase in herbage yield due to $\mathrm{N}$ varied from 336 to $943 \mathrm{lb}$./ acre for $\mathrm{N}$ rates of 20 and 200, respectively. These increases in herbage yield account for a total 6-year return ( $\mathrm{N}$ efficiency) of 33.6 to $9.4 \mathrm{lb}$. of herbage per $\mathrm{lb}$. of $\mathrm{N}$ for $\mathrm{N}$ rates of 20 and 200, respectively (Table 3).

\section{Discussion}

On these abandoned plowed fields, a decrcase in red threcawn is desirable, provided that it can be obtained without excessive losses of sand dropseed or excessive increases of slimleaf goosefoot. When evaluated for grazing by livestock, the most beneficial of $\mathrm{N}$ induced changes resulted from repeated applications of $20 \mathrm{lb}$. N/
Table 3. Mean annual increase in herbage yield (lb./acre) due to $\mathbf{N}$ and $\mathbf{N}$ efficiency (lb. herbage/lb. $\mathbf{N}$ applied).

\begin{tabular}{ccc}
\hline \hline $\begin{array}{c}\text { Nitrogen } \\
\text { rate } \\
\text { (lb./acre) }\end{array}$ & $\begin{array}{c}\text { Mean increase } \\
\text { in yield }\end{array}$ & $\begin{array}{c}\text { Mean N } \\
\text { efficiency }^{2}\end{array}$ \\
\hline 20 & 336 & 33.6 \\
40 & 339 & 17.0 \\
60 & 449 & 15.0 \\
100 & 900 & 18.0 \\
200 & 943 & 9.4 \\
\hline
\end{tabular}

\footnotetext{
${ }^{1}$ Nitrogen fertilizer was applicd in 3 consecutive years.

${ }^{2}$ Herbage yields were taken in 6 consecutive years. Mean increases are those amounts in excess of the mean yield on unfertilized plots averaged over the 6 years.
}

acre. However, to initiate a fast decrease in red threeawn, one could apply $60 \mathrm{lb}$. $\mathrm{N} /$ acre in the first year and continue fertilization at $20 \mathrm{lb}$. N/acre in subsequent years. The economic value and practical feasibility of this proposed fertilization program should be determined by grazing trials.

Plant mortality and secondary succession after fertilization for 3 years reveal differences among species in tolerance to $\mathrm{N}$. The secondary succession of annual species induced by 100 and $200 \mathrm{lb}$. N/acre is similar to that observed on freshly plowed areas, except that slimleaf goosefoot is essentially lacking on plowed soil. Succession on freshly plowed areas begins with prairie sunflower the first year and goes to Russianthistle the second year. Thereafter, succession proceeds to red threeawn and sand dropseed in different ways and at various rates. At the Aristida stage of secondary succession, red threeawn generally is dominant in a relatively static community that is quite undesirable for pasture. Red threeawn apparently closes the community and slows down further succession to terminal dominant and sub-dominant perennials such as scarlet globemallow (Sphaeralcea coccinea (Pursh) Rydb.), western wheatgrass (Agropyron smithii Rydb.), needleandthread (Stipa co- 
mata Trin. and Rupr.), sun sedge (Carex heliophila Mackenz.), and blue grama. An earlier than Aristida stage of succession in which sand dropseed, Russianthistle, and prairie sunflower dominate (as induced by nitrogen fertilization) should provide better pasture for cattle in the short run. This work suggests the need for additional research to determine whether con- tinuous fertilization at $20 \mathrm{lb} . \mathrm{N} /$ acre may cause succession to bypass the static Aristida stage and change botanical composition more quickly to terminal dominant and subdominant perennials. Long term grazing trials are needed to answer questions about economic advantages and successional trends under continuous fertilization at a low rate of nitrogen.

\section{Literature Cited}

Costello, D. F. 1944. Natural revegetation of abandoned plowed land in the mixed prairie association of northeastern Colorado. Ecology 25:312-326.

Hyder, D. N., A. C. Everson, and R. E. Bement. 1971. Seedling morphology and seeding failures with blue grama. J. Range Manage. 24: 287-292. 